\title{
Ретроперитонеоскопічна резекція нирки з передопераційною селективною емболізаціею та флуоресцентною візуалізаціею ниркових судин. Аналіз післяопераційних ускладнень
}

\begin{abstract}
Мета роботи: провести аналіз післяопераційних ускладнень у хворих на локальний рак нирки після проведення ретроперитонеоскопічної резекції нирки з передопераційною селективною емболізацією та флуоресцентною візуалізацією ниркових судин. Матеріали і методи. Ми прооперували 25 хворих на локальний рак нирки та виконали аналіз зареєстрованих післяопераційних ускладнень.

Результати досліджень та їх обговорення. Всім хворим на локальний нирково-клітинний рак нирки виконано резекцію нирки (ZERO ishemia) з використанням інтраопераційної флуоресцентної візуалізації в режимі інфрачервоної ділянки спектра за допомогою індоціаніну зеленого (Indocyanine green). На передопераційному етапі всім хворим виконували суперселективну рентгеноваскулярну емболізацію.

Аналіз ускладнень проводили за загальноприйнятою шкалою післяопераційних ускладнень Клав’єн-Діндо.

Під час виконання хірургічних втручань ускладнень не спостерігали. На передопераційному етапі зареєстровано одне, у післяопераційному етапі - лише 3 ускладнення (12 \%). Всі ускладення були I-II ступеня та не потребували повторної хірургічної корекції і не впливали на тривалість перебування в реанімаційному відділені та хірургічному стаціонарі, не призводили до проведення таких додаткових маніпуляцій та процедур, як гемотрансфузії, ендоскопічні та інтервеційні радіологічні втручання. Проведений аналіз зареєстрованих післяопераційних ускладнень після виконаної ретроперитонеоскопічної резекції з використанням передопераційної рентгеноваскулярної емболізації та інтраопераційної флуоресцентної візуалізації в режимі інфрачервоної ділянки спектра за допомогою індоціаніну зеленого (Indocyanine green) з певною часткою достовірності дає підстави $з$ урахуванням безпосередньої ефективності та практично повної відсутності інтра- і післяопераційних ускладнень рекомендувати переваги даної хірургічної методики.

Наведені дані свідчать, що використання суперселективної рентгеноваскулярної емболізації та інтраопераційної флуоресцентної візуалізації в хірургічному лікуванні локалізованого раку нирки порівняно зі “стандартним” методом хірургічного лікування має суттєві переваги. Ми вбачаємо перспективність продовження вивчення та впровадження запропонованого алгоритму обстеження та лікування хворих на локальний рак нирки.
\end{abstract}

Ключові слова: локалізований рак нирки; ретроперитонеоскопічна резекція; індоціанін зелений; суперселективна рентгеноваскулярна емболізація судин нирки.

Постановка проблеми i аналіз останніх досліджень та публікацій. Нирково-клітиний рак (НКР) впродовж останніх двох десятиріч має щорічний приріст частоти виникнення як в Європі, так і у світі і складає 2-3 \% серед усіх злоякісних пухлин. Частота захворюваності серед чоловіків у 1,5 раза вища, ніж серед жінок. Пік захворюваності доводиться на віковий рівень $60-70$ років $[1,2]$. Спираючись на статистичні дані, слід зазначити, що кількість хворих, яким виконують операції з приводу утворень нирки, кожен рік збільшується. Якщо у 80-х роках минулого сторіччя їхнє число складало 0,21 на 100 тис., то у $2002-1,6$, а вже у 2012 р. - 2,1 на 100 тис. населення. У 2017 р. загальна кількість первинних хворих НКР в Україні склала 4776 випадків, при цьому внаслідок хвороби померло 1944 пацієнти [3, 4].

Ключову роль у діагностиці злоякісних новоутворень нирок відіграє застосування комп’ютерної томографії $[5,6]$. Практично в усіх світових загальноприйнятих протоколах передопераційного обстеження КТ відіграє невід’ємну частину $[7,8]$. Цей метод найрозповсюдженіший завдяки відносно невеликої собівартості та високій інформативності. Однак судинну реконструкцію нирок під час передопераційної КТ діагностики виконують досить рідко, що є суттєвим недоліком $[9,10]$.

Нині у разі виявлення пухлин нирки невеликих розмірів, з метою підвищення інформативності визначення розташування кортикальних пухлин нирки, відношення до чашково-мискової системи, судин, наколишніх тканин та структур, у світі запропоновано декілька нефрометричних шкал, які дозволяють із достатньо великим відсотком ймовірності визначити ступінь резектабельністі пухлинного процесу. Серед найбільш розповсюджених: RENALscore, PADUAscore, C-index [11, 12, 13].

Незважаючи на достатньо велику кількість запропонованих нефрометричних шкал, єдиної загальноприйнятої сьогодні, на жаль, не існує. Це свідчить про наявність у кожній із них визначених недоліків. Кожен медичний заклад або центр, що 


\section{З ДОСВІДУ РОБОТИ}

надає хірургічну допомогу хворим на локальний рак нирки, має опції при виборі нефрометричних шкал, тому повністю систематизувати отриманий світовий досвід неможливо, враховуючи використання різних методів [14, 15].

На сьогодні основним та, без сумнівів, найефективнішим методом лікування локального раку нирки є хірургічний [16, 17].

Однак, незважаючи на накопичений суттєвий світовий досвід, такі питання, як тактика передопераційного обстеження $з$ метою найбільш точного визначення розташування пухлини, метод доступу, об’єм операції, необхідність виконання теплової ішемії під час резекції, інтраопераційні методи візуалізації пухлини нирки залишаються дискутабельними [18, 19$]$.

На сьогодні практично у всіх країнах світу методом вибору лікування локального раку нирки $є$ ендоскопічна резекція [20, 21]. Незважаючи на достатньо великий накопичений світовий досвід, відсоток ускладнень після резекції нирки зберігається на досить високому рівні, та за різноманітними даними складає від 3,3 до 10 \% [22, 23]. Ці ускладнення після резекції нирки найчастіше мають зв’язок із технічними особливостями проведення хірургічного втручання - мобілізація та дисекція ниркових судин, тривалість ішемії, об’єм ниркової паренхіми, яка видаляється, реконструкція чашково-мискової системи, оснащення медичного закладу обладнанням, досвід операційної бригади. Серед головних це інтраопераційна крововтрата та розвиток функціональної недостатності оперованої нирки у подальшому [24, 25].

3 метою мінімізації інтраопераційної крововтрати при резекціях нирки до нині виконується повна або часткова теплова ішемія органа [26, 27]. Це дозволяє хірургу оперувати у відносно “сухому” операційному полі, значно покращує візуалізацію, полегшує визначення кордонів розташування пухлини. Однак це має і негативні наслідки - під час дисекції навколишніх судин тканин, з метою їх візуалізації та контролю, зростає ризик їх травматизації, що може призвести до небажаних наслідків або навіть до нефректомії у зв'язку з неконтрольованою кровотечею [28, 29].

Крім того, спираючись на сучасний світовий досвід, зрозуміло, що будь-яка тривалість теплової ішемії під час операції негативно впливає на функцію оперованої нирки в подальшому, що може призвести до ниркової недостатності. Це засвідчують декілька великих багатоцентрових сучасних досліджень [30, 31].

Jan Ebbing et al. (2019) пропонують не використовувати інтраопераційну ішемію нирки під час резекції. У дослідження були включені 444 па- цієнти (211 хворим виконано лапароскопічну резекцію нирки, 233 - перенесли відкриту резекцію), у 57 випадках не використовували ішемію. Дослідження мало за мету проаналізувати відносно короткострокові та довгострокові зміни в швидкості клубочкової фільтрації після операційного втручання. На підставі отриманих даних автори визначають, що тимчасова теплова ішемія під час виконання резекції нирки визначена як значний фактор ризику для короткострокових відносних змін у швидкості клубочкової фільтрації та розвитку гострої ниркової недостатності. Водночас не було виявлено впливу ішемії на довгострокові відносні зміни у швидкості клубочкової фільтрації. Автори зробили висновок, що теплова інтраопераційна ішемія під час резекції нирки є значущим фактором розвитку гострого пошкодження нирок, хронічної хвороби нирок у хворих з порушеною базовою швидкістю клубочкової фільтрації [31].

Слід зазначити, що забезпечення надійного гемостазу під час операції на нирках при їх пухлинному ураженні можливо не тільки інтраопераційно шляхом теплової ішемії, а і безпосередньо перед операцією [32, 33, 34]. Одним із таких методів $є$ емболізація гілок ниркової артерії. Ця методика в операційній урології здебільшого використовується при пухлинах нирки великих розмірів або місцеворозповсюдженних пухлинних процесах [32, 33, 35].

Сьогодні вже зрозуміло, що використання селективної емболізації гілок ниркової артерії, що живить зону ймовірної резекції на передопераційному етапі, є доцільним, при цьому не потрібна інтраопераційна дисекція судин нирки, значно зменшується можливість травми судин, рівень крововтрати, покращується візуалізація операційного поля, кордонів “здорової” паренхіми та пухлини, стає недоцільним використання гемостатичних швів із захопленням значної частини паренхіми нирки, що у подальшому має негативне значення та спричиняє розвиток зниження функції оперованої нирки та розвиток нефросклерозу [36, 37].

3 урахуванням отриманих багатьма дослідженнями даних сьогодні алгоритм лікування хворих на рак нирки насамперед спрямований на мінімізацію обсягу вилученої частини органа і відповідно підвищення “функціональності” виконуваного хірургічного втручання [38, 39, 40].

В цілому, спираюсь на аналіз літературних даних, які наведені вище, щодо діагностики та хірургічного лікування локального раку нирки стає очевидним актуальність використання алгоритму, який включає:

- застосування таких адекватних методів діагностики, як КТ із використанням артеріальних ре- 
жимів для чіткого розуміння архітектоніки судин (враховуючи їх можливі варіації) з подальшою ретельною реконструкцією нирки з пухлиною, використовуючи одну із доступних нефрометричних шкал. Впроваджуючи дану методику, можливо 3 високим ступенем ймовірності визначити та розрахувати об’єм здорової паренхіми нирки та пухлини, визначити та відмітити гілку ниркової артерії, що живить ділянку нирки, де локалізується новоутворення (найчастіше це одна основна судина, за винятком розсипного типу кровопостачання нирки, що зустрічається відносно нечасто) [41, 42];

- використання на передопераційному етапі селективної або суперселективної емболізації гілок ниркової артерії, що живлять ділянку нирки 3 пухлиною. Дана методика достатньо проста у виконанні та має незаперечні переваги. Вона дозволяє знизити інтраопераційну крововтрату та ії наслідки за рахунок відсутності кровопостачання в таргетній ділянці, підвищує візуалізацію операційного поля, що дозволяє більш ретельно виконувати резекцію, запобігти інтраопераційній тепловій ішемії нирки, дисекції в ділянці судин, ризик їх травми.

- метод доступу. На сьогодні чіткої рекомендації щодо методу доступу при резекціях нирки не існує. Більшість авторів вважає, що вибір необхідно робити індивідуально, відповідно до досвіду хірурга, його та пацієнта вподобань, супутньої патології хворого та анамнезу. Однак слід зазначити, що ретроперитонеоскопічний доступ має деякі переваги порівняно з лапароскопічним. У хворих, яким використовували ретроперитонеоскопічний доступ, після операції практично відсутній больовий синдром, повністю відсутні порушення функції ШКТ. У разі виникнення ускладнень у вигляді сечової нориці хворі найчастіше не потребують повторних операційних втручань, також відсутня ймовірність утворення післяопераційних троакарних кил [43, 44].

Вищезазначений запропонований алгоритм діагностики і хірургічного лікування локального раку нирки є доцільним, має переваги порівняно зі стандартними методами та $є$ недостатньо вивченим.

Мета роботи: провести аналіз післяопераційних ускладнень у хворих на локальний рак нирки після проведення ретроперитонеоскопічної резекції нирки з передопераційною селективною емболізацією та флуоресцентною візуалізацією ниркових судин.

Матеріали і методи. Ми прооперували 25 хворих на локальний рак нирки та виконали аналіз зареєстрованих післяопераційних ускладнень.
Операційне лікування виконували на базі КП “Дніпровський обласний клінічний онкологічний диспансер”.

В усіх випадках новоутворення нирки були виявлені під час ультразвукової діагностики. В дев'яти випадках хворі зверталися за медичною допомогою у зв’язку з болем у поперековій ділянці різної інтенсивності, в інших - утворення були виявлені при УЗД. У подальшому всім хворим виконували комп’ютерну томографію з внутрішньовенним посиленням для вивчення архітектоніки судин нирок в артеріальну фазу та визначення судини нирки, що підлягала емболізації.

Наступним етапом лікування було проведення усім хворим ретроперитонеоскопічної резекції нирки (ZERO ishemia) з визначенням кордонів резекції за допомогою інтраопераційної флуоресцентної візуалізації в режимі інфрачервоної ділянки спектра з використанням індоціаніну зеленого (Indocyanine green).

Всього зареєстровано 4 ускладення, одне - передопераційне, три - післяопераційні. За шкалою Клав’ єн-Діндо [45], всі ускладнення віднесено до I-II ступеня.

Результати досліджень та їх обговорення. Всім хворим на локальний нирковоклітиний рак нирки виконано резекцію нирки (ZERO ishemia) 3 використанням інтраопераційної флуоресцентної візуалізації в режимі інфрачервоної ділянки спектра за допомогою індоціаніну зеленого (Indocyanine green). На передопераційному етапі всім хворим виконували суперселективну рентгеноваскулярну емболізацію 64 \% пацієнтів (16 хворих) були жінки, 36 \% (9 хворих) чоловіки. Вік пацієнтів в середньому склав 54,2 року (42-76 років). Всім хворим викунували ретроперитонескопічну резекцію нирки, конверсій у “відкритий” або лапароскопічний доступ не було. Операційне втручання в середньому тривало 88 хвилин (68123 хвилини). Рівень інтраопераційної крововтрати в середньому склав 120 мл (50-250 мл). Тривалість перебування в стаціонарі - 3,3 дні.

При морфологічному дослідженні у 16 хворих морфологічно веріфікований світлоклітинний нирково-клітинний рак (pT1acN0M0R0), у 6 - діагностовано світлоклітинний нирковоклітинний рак (pT1всN0M0R0), у 2 пацієнтів виявлено хромофобний варіант нирковоклітинного раку (pT1acN0M0R0), в одному випадку діагностовано ангіоміоліпому нирки. Аналіз ускладнень проводили використовуючи загальноприйняту шкалу післяопераційних ускладнень Клав’єн-Діндо.

Під час проведення хірургічних втручань ускладнень не зареєстровано. На передоперацій- 
ному етапі зареєстроване одне, у післяопераційному етапі всього зареєстровано 3 ускладнення (12\%). Всі ускладення були I-II ступеня та не потребували повторної хірургічної корекції і не впливали на тривалість перебування у реанімаційному відділенні та хірургічному стаціонарі, не призводили до проведення таких додаткових маніпуляцій та процедур, як гемотрансфузії, ендоскопічні та інтервеційні радіологічні втручання.

В одному випадку у хворого Ш., 64 років, на передопераційному етапі після виконаної селективної емболізації нижнього полюсу нирки спостерігали виражений постішемічний больовий синдром, який потребував введення наркотичних анальгетиків впродовж доби. Хворого виписали на третю післяопераційну добу. Післяопераційних ускладнень не зареєстровано. В одному випадку у хворого М., 59 років, на першу післяопераційну добу після виконаної ретроперитонеоскопічної полюсної резекції нирки з ушиванням чашково-мискової системи спостерігали рясну гематурію, яку усунули консервативно, хвору виписали через чотири доби у задовільному стані. У хворого М., 76 років, після ретроперитонеоскопічної фронтальної резекції нирки спостерігали формування зовнішньої сечової нориці. Зазначене ускладнення не потребувало хірургічної корекції, проліковано консервативно, у задовільному стані хворого виписали на четверту добу. У хворого О., 49 років, після ретроперитонеоскопічної фронтальної резекції нирки на першу та другу післяопераційну доби спостерігали лихоманку, яка потребувала додаткового введення антипіретиків (Paracetamolum). Антибактеріальну терапію не призначали. Хворого виписали на четверту добу в задовільному стані.

Висновки. Проведений аналіз зареєстрованих післяопераційних ускладнень після виконаної ретроперитонеоскопічної резекції з використан- ням передопераційної рентгеноваскулярної емболізації та інтраопераційної флуоресцентної візуалізації в режимі інфрачервоної ділянки спектра за допомогою індоціаніну зеленого (Indocyanine green) $з$ певною часткою достовірності дозволяє нам $з$ урахуванням безпосередньої ефективності та практично повної відсутності інтра- і післяопераційних ускладнень рекомендувати переваги даної хірургічної методики. Невелика кількість зареєстрованих ускладень були I-II ступеня за шкалою Клав'єн-Діндо та суттєво не впливали на стан хворих і час перебування в стаціонарі. Слід зауважити, що рівень крововтрати при даній методиці мінімальний, що також сприяє швидкому відновленню хворих у післяопераційному періоді. Необхідно також зазначити, що враховуючи доступ (ретроперитонеоскопічний), у хворих після операції був практично відсутній больовий синдром, хворі потребували введення НПЗС тільки у першу добу. При виконанні даного алгоритму хірургічного лікування хворих на локальний рак нирки у всіх випадках не спостерігали жодних післяопераційних порушень моторики шлунковокишкового тракту, які би потребували медикаментозної корекції. Також слід зазначити, що у хворих, яким виконується описаний об'єм хірургічного втручання, практично відсутня можливість виникнення троакарних кил.

Перспективи подальших досліджень. Використання суперселективної рентгеноваскулярної емболізації та інтраопераційної флуоресцентної візуалізації у хірургічному лікуванні локалізованого раку нирки порівняно із “стандартним" методом хірургічного лікування має суттєві переваги. Автори даної публікації вбачають перспективність продовження вивчення та впровадження запропонованого алгоритму обстеження та лікування хворих на локальний рак нирки.

\section{СПИСОК ЛІТЕРАТУРИ}

1. Chow W.-H. Epidemiology and risk factors for kidney cancer / W.-H. Chow, L. M. Dong, S. S. Devesa // Nat. Rev. Urol. 2010. - Vol. 7 (5). - P. 245-257.

2. International cancer seminars: a focus on kidney cancer / G. Scelo, J. N. Hofmann, R. E. Banks [et al.] // Ann. Oncol. 2016. - Vol. 27 (8). - P. 1382-1385.

3. Рак в Україні, 2017-2018. Захворюваність, смертність, показники діяльності онкологічної служби / 3. П. Федоренко, Л. О. Гулак, Ю. Й. Михайлович [та ін.] // Бюл. Нац. канцер-реєстру України. - К. : Нац. інститут раку, 2019. - № 20. 4. Рак в Україні, 2013-2014. Захворюваність, смертність, показники діяльності онкологічної служби / З. П. Федоренко, Л. О. Гулак, Ю. Й. Михайлович [та ін.] // Бюл. Нац. канцер-реєстру України. - К. : Нац. інститут раку, 2015. - № 16. - 104 с.

5. Diaz de Leon A. Imaging and screening of kidney cancer / A. Diaz de Leon, I. Pedrosa // Radiol. Clin. North Am. - 2017. Vol. 55 (6). - P. 1235-1250.

6. Kay F. U. Imaging of solid renal masses / F. U. Kay, I. Pedrosa // Urol. Clin. North Am. - 2018. - Vol. 45 (3). - P. 311-330.

7. Gray R. E. Renal cell carcinoma: Diagnosis and management / R. E. Gray, G. T. Harris // Am. Fam. Physician. - 2019. Vol. 99 (3). - P. 179-184.

8. Imaging for the diagnosis and response assessment of renal tumours / S. H. Rossi, D. Prezzi, C. Kelly-Morland, V. Goh // World J. Urol. - 2018. - Vol. 36 (12). - P. 1927-1942.

9. Relative computed tomography (CT) enhancement value for the assessment of microvascular architecture in renal cell carcinoma / A.-M. Ouyang, Z.-L. Wei, X.-Y. Su [et al.] // Med. Sci. 


\section{З ДОСВІДУ РОБОТИ}

Monit. - 2017. - Vol. 23. - P. 3706-3714.

10. Prognostic role of microvessel density in patients with renal cell carcinoma: A meta-analysis / S.-H. Cheng, J.-M. Liu, Q.-Y. Liu [et al.] // Int. J. Clin. Exp. Pathol. - 2014. - Vol. 7 (9). - P. 5855-5863.

11. Utility of the R.E.N.A.L.-Nephrometry scoring system in objectifying treatment decision / D. Canter, A. Kutikov, B. Manley [et al.] // Urology. - 2011. - Vol. 78 (5). - P. 1089-1094.

12. Brookman-May S. Utility of nephrometric score sin kidney cancer surgery / S. Brookman-May // European Urology Supplements. - 2016. - Vol. 15, Issue 2. - P. 37, 37a.

13. Kidney tumor location measurement using the $\mathrm{c}$ index method / M. N. Simmons, C. B. Ching, M. K. Samplaski [et al.] // J. Urol. - 2010. - Vol. 183 (5). - P. 1708-1713.

14. Сравнение значимости шкал нефрометрической оценки renal, padua, c-index для прогноза сложности лапароскопической резекции почки / Ю. Г. Аляев, Е. С. Сирота, Л. М. Рапопорт [и др.] // Онкоурология. - 2018. - Т. 14, № 1. - С. 36-46. 15. Сравнение нефрометрических систем при парциальной нефрэктомии по поводу почечноклеточного рака / Т. В. Шатылко, В. М. Попков, А. Ю. Королёв, Д. А. Чаусовский // Рос. мед.-биол. вестн. им. акад. И. П. Павлова. - 2017. - T. 25, № 1. - С. 2500-2546.

16. Nephron-sparing surgery in renal cell carcinoma: Current perspectives on technical issues / J. González, J. M. Cózar, A. Gómez, [et al.] // Curr. Urol. Rep. - 2015. - Vol. 16 (2). - P. 6.

17. Ljungberg B. Nephron-sparing surgery-strategies for partial nephrectomy in renal cell carcinoma / B. Ljungberg // Scand. J. Surg. - 2004. - Vol. 93 (2). - P. 126-131.

18. Ischemia techniques in nephron-sparing surgery: A systematic review and meta-analysis of surgical, oncological, and functional outcomes / F. Greco, R. Autorino, V. Altieri [et al.] // Eur. Urol. 2019. - Vol. 75 (3). - P. 477-491.

19. Comparison of warm and cold ischemia on renal function after partial nephrectomy / Y. Funahashi, Y. Yoshino, N. Sassa [et al.] // Urology. - 2014. - Vol. 84 (6). - P. 1408-1412.

20. Renal mass and localized renal cancer: AUA guideline / S. Campbell, R. G. Uzzo, M. E. Allaf [et al.] // J. Urol. - 2017. Vol. 198 (3). - P. 520-529.

21. The road to real zero ischemia for partial nephrectomy / J. A. Peña, M. Oliveira, D. C. Ochoa [et al.] // J. Endourol. - 2013. - Vol. 27 (7). - P. 936-942.

22. Comparison of costs and complications of radical and partial nephrectomy for treatment of localized renal cell carcinoma / B. Shekarriz, J. Upadhyay, H. Shekarriz [et al.] // Urology. 2002. - Vol. 59 (2). - P. 211-215.

23. Comparing long-term outcomes following radical and partial nephrectomy for cT1 renal cell carcinoma in young and healthy / W. S. Tan, S. Berg, A. P. Cole [et al.] // JNCI Cancer Spectrum. 2019. - Vol. 3, Issue 1. pkz003.

24. Outcome of kidney function after ischaemic and zero-ischaemic laparoscopic and open nephron-sparing surgery for renal cell cancer / J. Ebbing, F. Menzel, P. Frumento [et al.] // BMC Nephrol. - 2019. - Vol. 20. - P. 40.

25. Predictors of postoperative renal functional damage after nephron-sparing surgery / J. Qi, Y. Yu, T. Huang [et al.] // World J. Surg. Oncol. - 2013. - Vol. 11. - P. 216.

26. Techniques in Nephron-sparing surgery: A systematic review and meta-analysis of surgical, oncological, and functional outcomes / F. Greco, R. Autorino, V. Altieri [et al.] // Eur. Urol. 2019. - Vol. 75 (3). - P. 477-491.

27. Comparison of warm and cold ischemia on renal function after partial nephrectomy / Y. Funahashi, Y. Yoshino, N. Sassa [et al.] // Urology. - 2014. - Vol. 84 (6). - P. 1408-1412.
28. Intraoperative conversion from partial to radical nephrectomy: Incidence, predictive factors, and outcomes / F. G. Petros, S. K. Keskin, K.-J. Yu [et al.] // Urology. - 2018. - Vol. 116. - P. 114-119.

29. Partial nephrectomy versus radical nephrectomy for clinical T1b and T2 renal tumors: A systematic review and meta-analysis of comparative studies / M. C. Mir, I. Derweesh, F. Porpiglia [et al.] // Eur. Urol. - 2017. - Vol. 71 (4). - P. 606-617.

30. Renal ischemia and function after partial nephrectomy: A collaborative review of the literature / A. Volpe, M. L. Blute, V. Ficarra [et al.] // Eur. Urol. - 2015. - Vol. 68 (1). - P. 61-74.

31. Outcome of kidney function after ischaemic and zero-ischaemic laparoscopic and open nephron-sparing surgery for renal cell cancer / J. Ebbing, F. Menzel, P. Frumento [et al.] // BMC Nephrol. - 2019. - Vol. 20. - P. 40.

32. The impact to operation safety of preoperative renal artery embolization for management of diameter $\geq 10 \mathrm{~cm}$ renal cell carcinoma / Z. Jia, X. S. Li, C. J. Zhang [et al.] // Zhonghua wai ke za zhi [Chinese journal of surgery]. - 2017. - Vol. 55 (10). P. 738-741.

33. Renal artery embolization in a gross kidney neoplasm / G. Provenza, A. Sparagna, G. V. Cunsolo [et al.] // G. Chir. 2013. - Vol. 34 (9-10). - P. 263-266.

34. Superselective renal artery embolization for bleeding complications after percutaneous renal biopsy: a single-center experience / W. Haochen, W. Jian, S. Li [et al.] // J. Int. Med. Res. 2019. - Vol. 47 (4). - P. 1649-1659.

35. Value of preoperative renal artery embolization in reducing blood transfusion requirements during nephrectomy for renal cell carcinoma / C. W. Bakal, J. Cynamon, P. S. Lakritz, S. Sprayregen // J. Vasc. Interv. Radiol. - 1993. - Vol. 4, Issue 6. - P. 727-731.

36. Near-infrared fluorescence imaging to facilitate super-selective arterial clamping during zero-ischemia robotic partial nephrectomy / M. S. Borofsky, I. S. Gill, A. K. Hemal [et al.] // BJU Int. - 2013. - Vol. 111, Issue 4. - P. 604-610.

37. Systematic review and meta-analysis of comparative studies reporting perioperative outcomes of robot-assisted partial nephrectomy versus open partial nephrectomy / L. Xia, X. Wang, T. Xu, T. J. Guzzo// J. Endourol. - 2017. - Vol. 31 (9). - P. 893-909.

38. Partial nephrectomy versus radical nephrectomy for clinical localised renal masses / F. Kunath, S. Schmidt, L. M. Krabbe [et al.] // Cochrane Database of Syst. Rev. - 2017. - Vol. 2017, Issue 5. Art. No.: CD012045.

39. Systematic review of oncological outcomes following surgical management of localised renal cancer / S. MacLennan, M. Imamura, M. C. Lapitan [et al.] // Eur. Urol. - 2012. - Vol. 61 (5). P. 972-993.

40. Robot-assisted versus laparoscopic partial nephrectomy for anatomically complex T1b renal tumors with a RENAL nephrometry score $\geq 7$ : A propensity score-based analysis / W. Deng, J. Li, X. Liu [et al.] // Cancer Med. - 2020. - Vol. 9 (2). - P. 586-594. 41. A literature review of renal surgical anatomy and surgical strategies for partial nephrectomy / T. K. V. Ficarra, C. Gratzke, J. Kaouk [et al.] // Eur. Urol. - 2015. - Vol. 68 (6). - P. 980992.

42. Azhar R. A. Anatomic partial nephrectomy: Technique evolution / R. A. Azhar, C. Metcalfe, I. S. Gill // Curr. Opin. Urol. 2015. - Vol. 25 (2). - P. 95-99.

43. Comparison of transperitoneal and retroperitoneal laparoscopic nephrectomy for renal cell carcinoma: a systematic review and meta-analysis / X. Fan, K. Xu, T. Lin [et al.] // BJU Int. -2013. - Vol. 111, Issue 4. - P. 611-621.

44. Transperitoneal versus retroperitoneal laparoscopic partial nephrectomy: Patient selection and perioperative outcomes / 
C. S. Ng, I. S. Gill, A. P. Ramani [et al.] // J. Urol. - 2005. Vol. 174 (3). - P. 846-849.

45. Validation of the Clavien-Dindo grading system in urology by the European association of urology guidelines Ad Hoc Panel / D. Mitropoulos, W. Artibani, C. S. Biyani [et al.] // Eur. Urol. Focus. - 2018. - Vol. 4 (4). - P. 608-613.

\section{REFERENCES}

1. Chow, W.-H., Dong, L.M., \& Devesa, S.S. (2010). Epidemiology and risk factors for kidney cancer. Nat. Rev. Urol.,7 (5), 245-257.

2. Scelo, G., Hofmann, J.N., Banks, R.E., Bigot, P., Bhatt, R.S., Cancel-Tassin, G., ..., \& Vasudev, N.S. (2016). International cancer seminars: a focus on kidney cancer. Ann. Oncol., 27 (8), 13821385.

3. Fedorenko, Z.G., Gulak, L.O., Mihailovich, U.I. Horokh, Ye.L., Ryzhov, A.Yu., Sumkina, O.V., \& Kutsenko, L.B. (2019). Rak v Ukraini, 2017-2018. Zakhvoriuvanist, smertnist, pokaznyky diialnosti onkolohichnoi sluzhby [Cancer in Ukraine, 2017-2018. Morbidity, mortality, indicators of oncological service activity]. Byul. Nats. kantser-reiestru Ukrainy - Bull. Nat. Cancer Registry of Ukraine, 20. Kyiv: National Cancer Institute [in Ukrainian].

4. Fedorenko, Z.G., Gulak, L.O., Mihailovich, U.I. Horokh, Ye.L., Ryzhov, A.Yu., Sumkina, O.V., \& Kutsenko, L.B. (2019). Rak v Ukraini, 2013-2014. Zakhvoriuvanist, smertnist, pokaznyky diialnosti onkolohichnoi sluzhby [Cancer in Ukraine, 2017-2018. Morbidity, mortality, indicators of oncological service activity]. Byul. Nats. kantser-reyestru Ukrainy - Bull. Nat. Cancer Registry of Ukraine, 16. Kyiv: National Cancer Institute [in Ukrainian].

5. Diaz de Leon, A. \& Pedrosa, I. (2017). Imaging and screening of kidney cancer. Radiol. Clin. North Am., 55 (6), 1235-1250. 6. Kay, F.U., \& Pedrosa, I. (2018). Imaging of solid renal masses. Urol. Clin. North Am., 45 (3), 311-330.

7. Gray, R.E., \& Harris, G.T. (2019). Renal cell carcinoma: Diagnosis and management. Am. Fam. Physician, 99 (3), 179184.

8. Rossi, S.H., Prezzi, D., Kelly-Morland, C., \& Goh, V. (2018). Imaging for the diagnosis and response assessment of renal tumours. World J. Urol., 36 (12), 1927-1942.

9. Ouyang, A.-M., Wei, Z.-L., Su, X.-Y., Li, K., Zhao, D., Yu, D.-X., \& Ma. X.-X. (2017). Relative computed tomography (CT) enhancement value for the assessment of microvascular architecture in renal cell carcinoma. Med. Sci. Monit., 23, 3706-3714.

10. Cheng, S.-H., Liu, J.-M., Liu, Q.-Y., Luo, D.-Y., Liao, B.-H., Li, H., \& Wang K.-J. (2014). Prognostic role of microvessel density in patients with renal cell carcinoma: A meta-analysis. Int. J. Clin. Exp. Pathol., 7 (9), 5855-5863.

11. Canter, D., Kutikov, A., Manley, B., Egleston, B., Simhan, J., Smaldone, M., ..., \& Uzzo, R.G. Utility of the R.E.N.A.L.-Nephrometry scoring system in objectifying treatment decision. Urology, 78 (5), 1089-1094.

12. Brookman-May, S. (2016). Utility of nephrometric score sin kidney cancer surgery. European Urology Supplements, 15, 2, 37, 37a.

13. Simmons, M.N., Ching, C.B., Samplaski, M.K., Park, C.H., \& Gill, I.S. (2010). Kidney tumor location measurement using the c index method. J. Urol., 183 (5), 1708-1713.

14. Alyaev, U.G., Sirota, E.S., Rapoport, L.M., Bezrukov, E.A., Suhanov, R.B., \& Tsarichenko, D.G. (2018). Sravnenie znachimosti shkal nephrometricheskoi otsenki RENAL, PADUA, C-INDEX dlya prognoza slozhnosti laparoskopicheskoi rezektsii pochki [Comparison of significance of scales of nefrometric assessment renal, padua, c-index for forecasting complexity of lapa- roscopic kidney resection]. Oncourologiya-Oncourology, 14, 1, 36-46 [in Russian].

15. Shatilko, T.V., Popkov, V.M., Koroliov, A.U., \& Chausovskiy, D.A. (2017). Sravnenie nephrometricheskih system pri partsialnoi nephrektomii po povodu pochechnokletochnogo raka [Comparison of nephrometric systems in partial nephrectomy in patients with renal cell carcinoma]. Rosiiskiy mediko-biologicheskiy vestnik im. akad. I.P. Pavlova - Russian Medical and Biological Bulletin named after acad. I.P. Pavlova, 25, 1, 2500-2546 [in Russian].

16. González, J., Cózar, J.M., Gómez, A., Fernández-Pérez, C., \& Esteban, M. (2015). Nephron-sparing surgery in renal cell carcinoma: Current perspectives on technical issues. Curr. Urol. Rep., 16 (2), 6.

17. Ljungberg, B. (2004). Nephron-sparing surgery-strategies for partial nephrectomy in renal cell carcinoma. Scand. J. Surg., 93 (2), 126-131.

18. Greco, F., Autorino, R., Altieri, V., Campbell, S., Ficarra, V., Gill, I. ..., \& van Poppel, H. (2019). Ischemia techniques in nephron-sparing surgery: A systematic review and meta-analysis of surgical, oncological, and functional outcomes. Eur. Urol., 75 (3), 477-491.

19. Funahashi, Y., Yoshino, Y., Sassa, N., Matsukawa, Y., Takai, S., \& Gotoh, M. (2014). Comparison of warm and cold ischemia on renal function after partial nephrectomy. Urology, 84 (6), 1408-1412.

20. Campbell, S., Uzzo, R.G., Allaf, M.E., Bass, E.B., Cadeddu, J.A., \& Chang, A. (2017). Renal mass and localized renal cancer: AUA guideline. J. Urol., 198 (3), 520-529.

21. Peña, J.A., Oliveira, M., Ochoa, D.C., Santillana, J.M., Skrobot, S.A., Castellarnau, S., ..., \& Villavicencio, H. (2013). The road to real zero ischemia for partial nephrectomy. J. Endourol., 27 (7), 936-942.

22. Shekarriz, B., Upadhyay, J., Shekarriz, H., de Assis Mendes Goes Jr, F., Bianco, F.J., Tiguert, R., ..., \& Wood Jr, D.P. (2002). Comparison of costs and complications of radical and partial nephrectomy for treatment of localized renal cell carcinoma. Urology, 59 (2), 211-215.

23. Tan, W.S., Berg, S., Cole, A.P., Krimphove, M., Marchese, M., Lipsitz, S.R., Nabi, ..., \& Trinh, Q.-D. (2019). Comparing long-term outcomes following radical and partial nephrectomy for cT1 renal cell carcinoma in young and healthy. JNCI Cancer Spectr, 3 (1), pkz003.

24. Ebbing, J., Menzel, F., Frumento, P., Miller, K., Ralla, B., Fuller, T.F., ..., \& Kempkensteffen, C. (2019). Outcome of kidney function after ischaemic and zero-ischaemic laparoscopic and open nephron-sparing surgery for renal cell cancer. BMC Nephrol., 20, 40.

25. Qi, J., Yu, Y., Huang, T., Bai, Q., Kang, J., Liang, J., \& Wu, Y. (2013). Predictors of postoperative renal functional damage after nephron-sparing surgery. World J. Surg. Oncol., 11, 216.

26. Greco, F., Autorino, R., Altieri, V., Campbell, S., Ficarra, V., Gill, I., ..., \& van Poppel, H. (2019). Techniques in Nephronsparing surgery: A systematic review and meta-analysis of surgical, oncological, and functional outcomes. Eur. Urol., 75 (3), 477-491. 
27. Funahashi, Y., Yoshino, Y., Sassa, N., Matsukawa, Y., Takai, S., \& Gotoh, M. (2014). Comparison of warm and cold ischemia on renal function after partial nephrectomy. Urology, 84 (6), 1408-1412.

28. Petros, F.G., Keskin, S.K., Yu, K.-J., Li, R., Metcalfe, M.J., Fellman, B.M., ..., \& Wood, C.G. (2018). Intraoperative conversion from partial to radical nephrectomy: Incidence, predictive factors, and outcomes. Urology, 116, 114-119.

29. Mir, M.C., Derweesh, I., Porpiglia, F., Zargar, H., Mottrie, A., \& Autorino, R. (2017). Partial nephrectomy versus radical nephrectomy for clinical T1b and T2 renal tumors: A systematic review and meta-analysis of comparative studies. Eur. Urol., 71 (4), 606-617.

30. Volpe, A., Blute, M.L., Ficarra, V., Gill, I.S., Kutikov, A., Porpiglia, F., ..., \& Thompson, R.H. (2015). Renal ischemia and function after partial nephrectomy: A collaborative review of the literature. European Urology, 68 (1), 61-74.

31. Ebbing, J., Menzel, F., Frumento, P., Miller, K., Ralla, B., Fuller, T.F., ..., \& Kempkensteffen, C. (2019). Outcome of kidney function after ischaemic and zero-ischaemic laparoscopic and open nephron-sparing surgery for renal cell cancer. BMC Nephrol., 20, 40.

32. Jia, Z., Li, X.S., Zhang, C.J., Yang, K.W., Peng, D., Yang, J.H., .., \& Zhou, L.Q. (2017). The impact to operation safety of preoperative renal artery embolization for management of diameter $\geq 10 \mathrm{~cm}$ renal cell carcinoma. Zhonghua wai ke za zhi, 55 (10), 738-741.

33. Provenza, G., Sparagna, A., Cunsolo, G.V., Tierno, S.M., Centanini, F., Bellotti, C., \& Mezzetti, G. (2013). Renal artery embolization in a gross kidney neoplasm. G. Chir., 34 (910), 263-266.

34. Haochen, W., Jian, W., Li, S., Tianshi, L., Xiaoqiang, T., \& Yinghua, Z. (2019). Superselective renal artery embolization for bleeding complications after percutaneous renal biopsy: a singlecenter experience. J. Int. Med. Res., 47 (4), 1649-1659.

35. Bakal, C.W., Cynamon, J., Lakritz, P.S., \& Sprayregen, S. (1993). Near-infrared fluorescence imaging to facilitate super-selective arterial clamping during zero-ischemia robotic partial nephrectomy. J. Vasc. Interv. Radiol., 4, 6, 727-731.

36. Borofsky, M.S., Gill, I.S., Hemal, A.K., Marien, T.P., Jayarat- na, I., Krane, L.S., \& Stifelman, M.D. (2017). Near-infrared fluorescence imaging to facilitate super-selective arterial clamping during zero-ischemia robotic partial nephrectomy. BJU Int., 111, 604-610.

37. Xia, L., Wang, X., Xu, T., \& Guzzo, T.J. (2017). Systematic review and meta-analysis of comparative studies reporting perioperative outcomes of robot-assisted partial nephrectomy versus open partial nephrectomy. J. Endourol., 31 (9), 893-909.

38. Kunath, F., Schmidt, S., Krabbe, L.M., Miernik, A., Dahm, P., Cleves, A., Walther, M., \& Kroeger, N. (2017). Partial nephrectomy versus radical nephrectomy for clinical localised renal masses. Cochrane Database of Syst. Rev., 2017, 5, Art. No.: CD012045. 39. MacLennan, S., Imamura, M., Lapitan, M.C., Omar, M.I., Lam, T.B.L., Hilvano-Cabungcal, A.M., ..., \& N'Dow, J. (2012). Systematic review of oncological outcomes following surgical management of localised renal cancer. Eur. Urol., 61 (5), 972-993. 40. Deng, W., Li, J., Liu, X., Chen, L., Liu, W., Zhou, X., ..., \& Wang, G. (2020). Robot-assisted versus laparoscopic partial nephrectomy for anatomically complex T1b renal tumors with a RENAL nephrometry score $\geq 7$ : A propensity score-based analysis. Cancer Med., 9 (2), 586-594.

41. Klatte, T., Ficarra, V., Gratzke, C., Kaouk, J., Kutikov, A., Macchi, V., ..., \& Porpiglia, F. (2015). A literature review of renal surgical anatomy and surgical strategies for partial nephrectomy. Eur. Urol., 68 (6), 980-992.

42. Azhar, R.A., Metcalfe, C., Gill, I.S., \& Azhar R.A. (2015). Anatomic partial nephrectomy: Technique evolution. Curr. Opin. Urol., 25 (2), 95-99.

43. Fan, X., Xu, K., Lin, T., Liu, H., Yin, Z., Dong, W., Huang, H., \& Huang, J. (2013). Comparison of transperitoneal and retroperitoneal laparoscopic nephrectomy for renal cell carcinoma: a systematic review and meta-analysis. BJU Int., 111, 4, 611-621.

44. Ng, C.S., Gill, I.S., Ramani, A.P., Steinberg, A.P., Spaliviero, M., Abreu, S.C., ..., \& Desai, M.M. (2005). Transperitoneal versus retroperitoneal laparoscopic partial nephrectomy: Patient selection and perioperative outcomes. J. Urol., 174 (3), 846-849. 45. Mitropoulos, D., Artibani, W., Biyani, C.S., Jensen, J.B., Rouprêt, M., \& Truss, M. (2018). Validation of the Clavien-Dindo grading system in urology by the European association of urology guidelines Ad Hoc Panel. Eur. Urol. Focus, 4 (4), 608-613.

Отримано 14.05.2020

Електронна адреса для листування: rewetnyak2011@gmail.com

\section{U. V. DUMANSKIY, O. I. BALASHOVA, S. O. RESHETNIAK, R. E. KAVETSKY}

Institute of Experimental Pathology, Oncology and Radiobiology, NAS of Ukraine, Kyiv, Dnipro Regional Oncological Centre, Dnipro

\section{RETROPERITONEOSCOPIC KIDNEY RESECTION WITH PREOPERATIVE SELECTIVE EMBOLIZATION AND FLUORESCENT VISUALIZATION OF RENAL VESSELS. ANALYSIS OF POSTOPERATIVE COMPLICATIONS}

\footnotetext{
The aim of the work: to analyze postoperative complications in patients with local kidney cancer after retroperitoneoscopic resection of the kidney with preoperative selective embolization and fluorescent imaging of renal vessels.

Materials and Methods. We operated on 25 patients with local kidney cancer and performed an analysis of registered postoperative complications.

Results and Discussion. All patients with local renal cell carcinoma of the kidney underwent resection of the kidney (ZERO ishemia) using intraoperative fluorescent imaging in the infrared region of the spectrum using Indocyanine green. At the preoperative stage, all patients underwent superselective X-ray vascular embolization. Complications were analyzed using the generally accepted ClavienDindo postoperative complications scale.
} 
No complications were reported during surgery. One complication was registered at the preoperative stage, and only 3 complications (12\%) were registered in the postoperative stage. All complications were of degrees 1-2, and did not require re-surgical correction and did not affect the length of stay in the intensive care unit and surgical hospital, did not require additional manipulations and procedures such as blood transfusions, endoscopic and interventional radiological interventions.

The analysis of the registered postoperative complications after retroperitoneoscopic resection using preoperative X-ray vascular embolization and intraoperative fluorescent imaging in the infrared region of the spectrum with indoctanine and postoperative complications, recommend the benefits of this surgical technique.

These data suggest that the use of superselective X-ray vascular embolization and intraoperative fluorescent imaging in the surgical treatment of localized kidney cancer has significant advantages over the "standard" method of surgical treatment. The authors of this publication see the prospects for further study and implementation of the proposed algorithm for examination and treatment of patients with local kidney cancer.

Key words: localized kidney cancer; retroperitoneoscopic kidney resection; indocyanine green; superselective X-ray vascular embolization of the kidney.

\author{
Ю. В. ДУМАНСКИЙ, О. И. БАЛАШОВА, С. А. РЕШЕТНЯК
}

Институт экспериментальной патологии, онкологии и радиобиологии имени Р. Е. Кавецкого НАН Украины, Киев КП “Днепровский областной клинический онкологический диспансер” ДОС, Днепр

\title{
РЕТРОПЕРИТОНЕОСКОПИЧЕСКАЯ РЕЗЕКЦИЯ ПОЧКИ С ПРЕДОПЕРАЦИОННОЙ СЕЛЕКТИВНОЙ ЭМБОЛИЗАЦИЕЙ И ФЛУОРЕСЦЕНТНОЙ ВИЗУАЛИЗАЦИЕЙ ПОЧЕЧНЫХ СОСУДОВ. АНАЛИЗ ПОС.ЛЕОЕРАЦИОННЫХ ОСЛОЖНЕНИЙ
}

Цель работы: провести анализ послеоперационных осложнений у больных на локальный рак почки после проведения ретроперитонеоскопической резекции почки с предоперационной селективной эмболизацией и флуоресцентной визуализацией почечных сосудов.

Материалы и методы. Мы прооперировали 25 пациентов с локальным раком почки и провели анализ зарегистрированных послеоперационных осложнений.

Результаты исследований и их обсуждение. Всем больным на локальный почечно-клеточный рак выполнена резекция почки (ZERO ishemia) с использованием интраоперационной флуоресцентной визуализации в режиме инфракрасного спектра света с использованием индоцианина зеленого (Indocyanine green). На предоперационном этапе всем больным выполнялась суперселективная рентгеноваскулярная эмболизация.

Анализ осложнений проводили используя общепринятую шкалу послеоперационных осложнений Клавьен-Диндо.

При проведении хирургических вмешательств интраоперационных осложнений не зарегистрировано. На предоперационном этапе зарегистрировано одно, в послеоперационном этапе - всего 3 осложнения (12 \%). Все осложнения были I-II степени, и не нуждались в повторной хирургической коррекции и не влияли на продолжительность пребывания в реанимационном отделении и хирургическом стационаре, не требовали проведения таких дополнительных манипуляций и процедур, как гемотрансфузии, эндоскопические и интервеционные радиологические вмешательства.

Проведенный анализ зарегистрированных послеоперационных осложнений после выполненной ретроперитонеоскопической резекции с использованием предоперационной рентгеноваскулярной эмболизации и интраоперационной флуоресцентной визуализации в режиме инфракрасного спектра света с использованием индоцианина зеленого (Indocyanine green) с определенной долей достоверности позволяет нам с учетом непосредственной эффективности и практически полного отсутствия интраи послеоперационных осложнений рекомендовать преимущества данной хирургической методики.

Приведенные данные свидетельствуют о том, что использование суперселективной рентгеноваскулярной эмболизации и интраоперационной флуоресцентной визуализации в хирургическом лечении локализованного рака почки по сравнению с “обычным” методом хирургического лечения имеет существенные преимущества. Мы видим перспективность продолжения изучения и внедрения предложенного алгоритма обследования и лечения больных с локальным раком почки.

Ключевые слова: локализованный рак почки; ретроперитонеоскопическая резекция; индоцианин зеленый; суперселективная рентгеноваскулярная эмболизация сосудов почки. 